\title{
Optimising pasture production to minimise weed growth
}

\author{
J.P.J. EERENS, A. RAHMAN and T.K. JAMES \\ AgResearch, Ruakura Research Centre, Private Bag 3123, Hamilton \\ han.eerens@agresearch.co.nz
}

\begin{abstract}
Weeds are part of any land based production system and need to be managed appropriately to minimise their negative impact on economic returns. Too frequently herbicides are used routinely to cure the weed problem without examining the underlying cause of the problem. Routine herbicide use poses risks to the environment and damages New Zealand's 'Clean and Green' image, therefore alternative weed management strategies need to be considered. In pasture based systems, ensuring that the forage species are in prime condition all year round is the method of choice to reduce weed problems to sub-economic levels. Forage grasses are very competitive, so much so that they often prevent significant contributions from companion species like white clover. In an experiment Californian thistle was grown in pasture maintained at two different height ranges. Maintaining a longer pasture significantly reduced Californian thistle shoot production, while not affecting total forage production. It is concluded that maintaining longer pasture residuals not only slightly increased pasture production, it also minimised weed problems and should therefore be the choice weed control strategy for pastoral farmers, wherever possible. Keywords: Californian thistle, grazing, pasture management, weed management
\end{abstract}

\section{Introduction}

Weed management is an important component of modern day farming as weeds prevent the optimisation of economic returns. Similar to other aspects of farming, the cost of weed management needs to be balanced against improved short and long term economic returns. Problems occur when the focus is biased towards dealing with weed problems as and when they occur, a reactive approach. Current weed control strategies on many farms that are based on routine herbicide use are expensive, damage the environment and are labour intensive. On dairy farms herbicide use is about seven times higher than on dry-stock farms (Holland \& Rahman 1999). This is not surprising as dairy farms tend to occupy land areas more easily accessible to machinery and suitable to high intensity farming. In $1997 / 98$ around 825 tonnes of active ingredient of pesticides was distributed over about 13 million ha of pastoral farm land, phenoxy hormones being the biggest group (68\%) (Holland \& Rahman 1999). While it is difficult to compare these usage figures internationally due to vastly different land use systems and farming intensities, New Zealand farmers could benefit from striving to live up to the 'Clean and Green' image that gives them a competitive advantage in overseas markets.

Increasing environmental concerns have forced governments in many developed nations to adopt policies to reduce pesticide usage in order to reduce environmental degradation and pollution, and to reduce public health risks (Watts 1997). At the same time the increasing globalisation of world trade and the elimination of tariffs as a legitimate barrier between trading nations will see a shift towards non-tariff barriers such as chemical residues, fossil fuels required to bring a product to the market and sustainability of farming practices. To avoid New Zealand's produce being denied access to the most lucrative markets, farmers could adopt alternatives to pesticides while maintaining (or increasing) productivity.

The objective in this paper is to demonstrate that pasture management is a powerful tool to restrict weed problems to sub-economic levels with only the occasional need for chemical weed control. Weed life stages, like pasture growth patterns, are cyclic in nature with recurring vulnerable periods which are potentially the most effective times to achieve optimal weed control in pastures. The focus of this paper is to show that grass farming with minimal chemical input is possible and effective, reduced inputs in addition to slightly improved pasture productivity and a greater contribution of sown species to the total production is also likely to improve profitable. This will be illustrated with the summary of a Californian thistle (Cirsium arvense) experiment carried out in 2001/02, after first discussing current weed control and herbicide use practices in pasture.

\section{Current weed control practices}

Weed problems are often either not recognised in time or ignored until they have developed into mature plants and have severely interfered with pasture production and/or quality. Typically herbicides are applied to deal with the problem. To be effective at that stage requires high rates of herbicide or high labour inputs and the results are not always satisfactory. The mode of action of many herbicides makes them particularly effective against either monocotyledons or dicotyledons and sometimes both. Consequently the combination of a grass and a 
legume in most New Zealand pastures makes weed control more difficult than the grass monocultures grown elsewhere. Older white clover cultivars tended to be relatively dormant over winter, offering a window of opportunity to control persistent dicotyledonous weeds. More recently, winter active material from the Mediterranean area has been bred into white clover resulting in either pseudo-dormancy or absence of winter dormancy (Caradus et al. 1995), which limits the range of herbicides that can be used. Since herbicides place a high selective pressure on weed populations, repeated use of herbicides with a similar mode of action speeds up the development of herbicide resistance rendering continued use of that herbicide unsatisfactory or ineffective. Herbicide resistance is now common in some of the most difficult to control weeds such as giant buttercup and nodding thistle (Rahman et al. 2001). Unless herbicides are used in a more judicious way (eg. by using chemicals with different modes of action), herbicide resistance may develop at a faster rate than new products can be developed.

\section{Pasture management to minimise weed problems}

The most effective weed control targets growing conditions before weeds have emerged following the principle that prevention is better than curing. In pastures the focus should be on optimising growth conditions which is achieved by optimising environmental conditions (soil fertility, $\mathrm{pH}$, soil moisture), selecting the best plant species/cultivar for the conditions (soil type, climate), and managing the defoliation regime (stocking density and rotation length). Farmers can influence all of these factors except the climate, but by applying knowledge from past experiences even the impact of the climate can be minimised. The key outcome needs to be to raise the competitive ability of forage species to a level that denies weed species any opportunity to successfully compete for resources.

Weeds are opportunistic in nature, and will by force of numbers successfully compete with pasture species for light, space, moisture and nutrients. There are a large number of weed seeds at varying depths in the soil. In a permanent pasture seeds found close to the surface are the most important as new seedlings are likely to emerge from here. The viability of seeds in the top $20 \mathrm{~mm}$ of the soil decreases over time, more rapidly for nodding thistle: 3-6 years (James et al. 1998) than for ragwort: 11-14 years (James \& Rahman 2000) and Californian thistle: 8-16 years (James \& Rahman 2001). However, Californian thistle plants are more $(>90 \%)$ likely to develop from rhizomes than from seed (Edwards et al. 2000).

Seedlings are at a disadvantage compared with established plants because they lack an established root system to source nutrients from the soil and have virtually no photosynthetic ability resulting in a slower growth rate than that of established plants. Successful weed establishment therefore has to occur in gaps in the pasture that are big enough to minimise the competition from established plants, but small enough to not alter the local microclimate. Panetta \& Wardle (1992) showed for three weed species that fewer seedlings emerged on bare ground than in gaps of $20-100 \mathrm{~mm}$, while the reverse held for clover species (white, subterranean and red). Gaps in pasture occur when established plants die, often as a result of overgrazing, pasture pulling, insect or pugging damage, or death of existing weeds. Overgrazing, especially during summer, exposes the soil to direct solar radiation which can result in high temperatures, in the upper soil layers, that are lethal for many plant parts. This can be overcome by maintaining pasture heights (residual dry matter) at slightly higher levels to prevent the soil from being exposed to direct radiation and also leaves the plant with more leaf area, speeding up pasture regrowth. Maintaining higher dry matter residuals after grazing is an effective means of preventing weed seedlings from establishing (Rahman et al. 1990). The impact of different pasture residuals has been studied over the years for several weeds, eg. nodding thistle and ragwort, and the main results will be summarised here as well as the results of an experiment into the interaction between pasture height and Californian thistle growth. The full report on the experiment is published elsewhere (Eerens et al. 2002).

\section{Californian thistle experiment Material and methods}

Californian thistle seedlings (5) were on 23 October 2001 transplanted at $150 \mathrm{~mm}$ spacing into 8 week old pasture (ryegrass/white clover) swards established in 20 containers per treatment, measuring 0.33 (l) $\mathrm{x} 0.33(\mathrm{w}) \mathrm{x}$ 0.36 (d) $\mathrm{m}$ at the Ruakura Research Centre. The pasture was cut at different heights (from $60 \mathrm{~mm}$ down to 20 $\mathrm{mm}$ and $150 \mathrm{~mm}$ to $100 \mathrm{~mm}$ ) as required when the plants had reached the upper height limit, while no pasture was sown in a third treatment. The treatments were replicated four times and a complete set of replicated containers was harvested every month for five months. At harvest, Californian thistle plants were cut off at ground level, the number of shoots per plant were counted, and then dried and weighed. From each replicate, a single centrally located Californian thistle plant was dug up and the number of subterranean shoots was counted, and root and shoot material was dried and weighed. Californian thistle biomass was estimated fortnightly between harvests by converting height and plant diameter measurements using the California thistle standard curve, 
$\mathrm{DM}=0.002 *\left[\sqrt{ }\left(\text { diameter }^{2}+\text { height }^{2}\right)\right]^{2.1813}$. Ryegrass tiller numbers were counted at each harvest and all herbage cut during the trial was collected, dried and weighed.

\section{Results and discussion}

The growth of Californian thistle was reduced when pasture was allowed to grow to $150 \mathrm{~mm}$ compared with $60 \mathrm{~mm}$ and in the absence of pasture (Figure 1). Not only was shoot dry matter affected but the number of shoots per plant was also reduced when pasture was thistle populations. Matthews \& Thompson (1977) suggested that mature ragwort plants would be better controlled by allowing them to flower, die naturally and then combat the seedlings when they emerge. These authors also suggested the additional use of $0.5 \mathrm{~kg} / \mathrm{ha}$ 2,4-D in autumn/early winter, but that was before the modern more winter active white clover cultivars were developed. It is unlikely that a serious Californian thistle problem can be remedied by pasture management alone, but chemical interference may not be necessary. Repeated topping of the shoots may be required for up to two

Figure 1 The mean dry weight (closed symbol measured and open symbol estimated) of Californian thistle plants grown with ryegrass/white clover cut at two different heights and without pasture. Bars indicate $\operatorname{LSD}_{0.05}$.

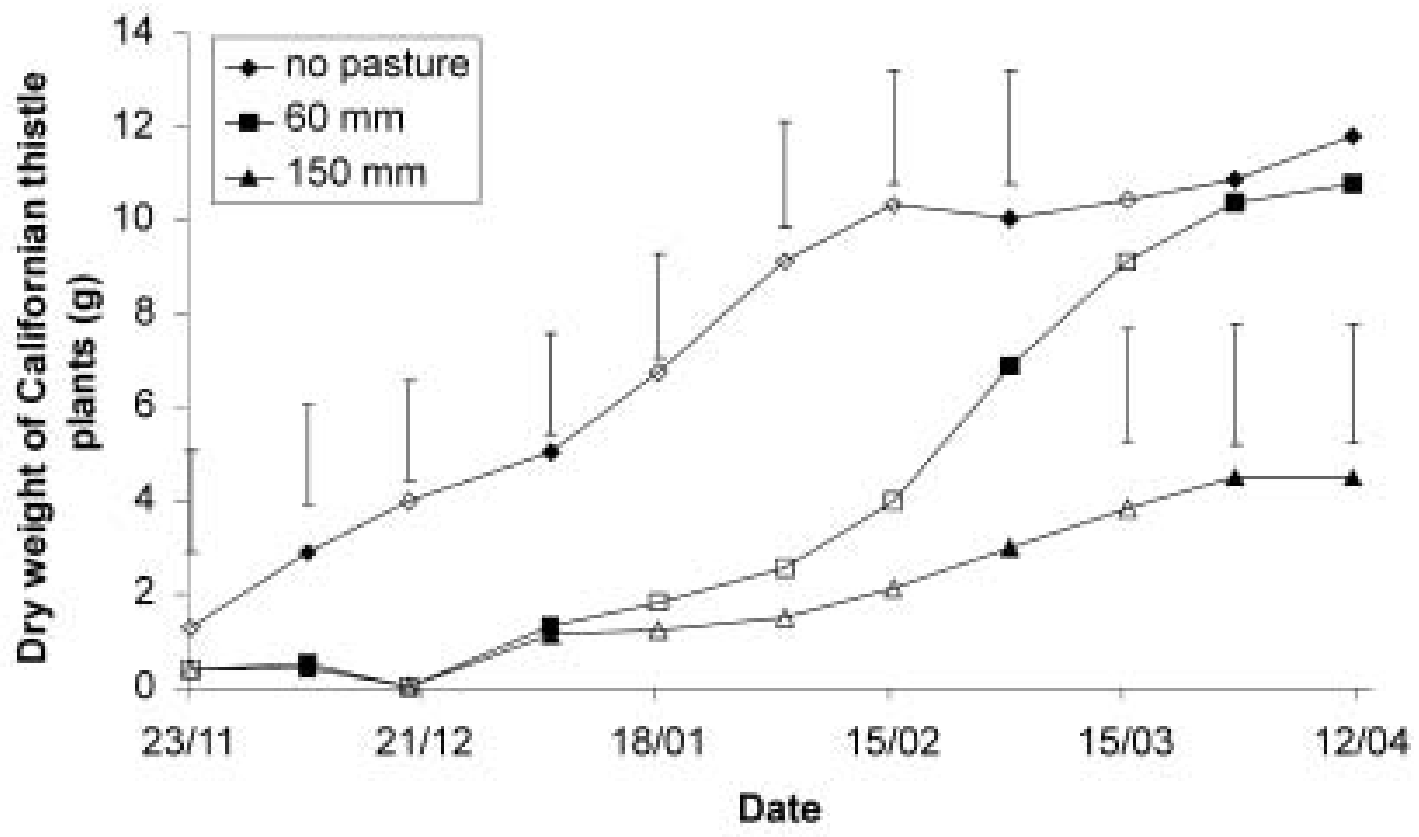

kept longer (data not shown). At the same time pasture production was slightly (not significantly) higher when a longer pasture was maintained (data not presented). At the final harvest ryegrass tiller numbers in the longer sward were more than double that in the shorter pasture (data not presented). The latter treatment is comparable to a set stocked sheep grazing, while the longer treatment resembles a fast rotational grazing with dairy heifers.

Similar effects of pasture height (or residuals) were obtained by Edwards et al. (2000) for Californian thistle and by Wardle et al. (1992) for nodding thistle, while Thompson \& Saunders (1986) and Rahman et al. (1990) made similar observations for ragwort in combination with fertilisers. Maintaining a strong sward in autumn when most seedlings emerge (Popay \& Thompson 1980) proved a highly effective method to control nodding years to reduce the thistle population (Hartley \& James 1979). Young emerging shoots can be grazed off by livestock (Mitchell \& Abernethy 1993), but it is important to top or graze several times in a season and at least once late in the season to prevent thistles from building up their reserves.

While some grass species (Yorkshire fog and ryegrass) are more effective than others in preventing nodding thistle seedling development (Wardle et al. 1992), maintaining a strong sward in the autumn is the most effective method to control nodding thistle seedlings (Popay \& Thompson 1980). The situation is very similar to control of ragwort, in which seedlings emerge shortly after the seed is formed in the autumn and are most effectively controlled by having a dense closed sward (Matthews 1976). 


\section{Conclusions}

Maintaining a longer pasture provides an effective and economic method of managing difficult to control weeds especially those that develop from seed such as ragwort and nodding thistle. Californian thistle develops from root stock and is more competitive than the seed derived weeds and requires more effort to achieve good control.

\section{REFERENCES}

Caradus, J.R.; Woodfield, D.R.; Stewart, A.V. 1995. Overview and vision for white clover. White Clover: New Zealand's Competitive Edge. Agronomy Society of New Zealand Special Publication 11/ Grassland Research and Practice Series 6: 1-6.

Edwards, G.R.; Bourdôt, G.W.; Crawley, M.J. 2000. Influence of herbivory, competition and soil fertility on the abundance of Cirsium arvense in acid grassland. Journal of Applied Ecology 37: 321-334.

Eerens, J.P.J.; Seefeldt, S.S.; Garry, G.; Armstrong, M.L. 2002. Controlling Californian thistle (Cirsium arvense) through pasture management. New Zealand Plant Protection 55: 111-115.

Hartley, M.J.; James, T.K. 1979. Cost benefit of selective control of Californian thistle in pasture. Proceedings of the New Zealand Weed and Pest Control Conference 32: 245-249.

Holland, P.; Rahman, A. 1999. Review of trends in agricultural pesticide use in New Zealand. MAF Policy Technical Paper 99/11.

James, T.K.; Rahman, A. 2000. Longevity of buried ragwort seed in four soils. New Zealand Plant Protection 53: 253-257.

James, T.K.; Rahman, A. 2001. Longevity of buried Cirsium arvense seed in four New Zealand soils. Proceedings of the Asian-Pacific Weed Science society Conference 18: 33-38.

James, T.K.; Rahman, A.; Wardle, D.A.; Bonner, K.I.
1998. Survival of nodding thistle (Carduus nutans) seed buried at different depths in four soils. Proceedings of the New Zealand Plant Protection Conference 51: 33-37.

Matthews, L.J. 1976. The journal guide to weed control. New Zealand Journal of Agriculture 133: 38-48.

Matthews, L.J.; Thompson, A. 1977. Ragwort control through seeding then spraying. Proceedings of the Ruakura Farmers' Conference 29: 6-7.

Mitchell, R.B.; Abernethy, R.J. 1993. Integrated management of Californian thistle in pasture. Proceedings of the New Zealand Plant Protection Conference 46: 278-281.

Panetta, F.D.; Wardle, D.A. 1992. Gap size and regeneration in a New Zealand dairy pasture. Australian Journal of Ecology 17: 169-175.

Popay, A.I.; Thompson, A. 1980. Nodding thistle: its growth and control. Proceedings of the Ruakura Farmers' Conference 32: 63-69.

Rahman, A.; James, T.K.; Seefeldt, S. 2001. The current situation with herbicide resistant weeds in New Zealand. Proceedings of the Asian-Pacific Weed Science Symposium 18: 500-508.

Rahman, A.; Thompson, A.; Nicholson, K.S. 1990. Ragwort control with herbicides and fertilisers: first year's results. Proceedings of the New Zealand Grassland Association 51: 65-68.

Thompson, A.; Saunders, A.E. 1986. The effect of fertiliser on ragwort in pasture. Proceedings of the New Zealand Weed and Pest Control Conference 39: 175-178.

Wardle, D.A.; Nicholson, K.S.; Rahman, A. 1992. Influence of pasture grass and legume swards on seedling emergence and growth of Carduus nutans $\mathrm{L}$. and Cirsium vulgare, L. Weed Research 32: 119-128.

Watts, M. 1997. Proposal for a pesticide risk reduction policy for New Zealand. Proceedings of the New Zealand Plant Protection Conference 50: 498-505. 